\title{
Time-related factors for peripheral intravenous catheterization of critical children
}

\author{
Fatores relacionados ao tempo para a cateterização intravenosa periférica de crianças críticas
}

Factores asociados con el tiempo en la cateterización intravenosa periférica de niños en situación crítica

'Universidade Federal de São Paulo. São Paulo, São Paulo, Brazil.

How to cite this article:

Floriano CMF, Avelar AFM, Peterlini MAS. Time-related factors for peripheral intravenous catheterization of critical children. Rev Bras Enferm. 2019;72(Suppl 3):58-64. doi: http://dx.doi.org/10.1590/0034-7167-2017-0856

Corresponding Author:

Claudia Maria de Freitas Floriano E-mail:cmffloriano@gmail.com

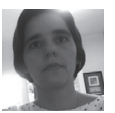

Submission: 12-02-2017

\section{ABSTRACT}

Objective:To verify characteristics related to critical children, the catheter, and the professionals that will influence the time for the success of the puncture. Method: Descriptive, prospective, and correlation study, collected with an unique instrument, and a sample consisting of 89 children cared for in the emergency room. Statistical analysis of the association between time and explanatory variables was performed, considering a significance of $5 \%$. Result: The median time for success was 193.4 seconds. Multivariate analysis showed that hypothermic patients $(p=0.009)$ presented prolonged times for success and that the puncture was performed in a shorter time with Vialon ${ }^{\oplus} 22 \mathrm{G}$ catheters $(p=0.045)$. Conclusion: The median time for success was higher than recommended, being influenced by hypothermia and condition of veins the children. The Vialon ${ }^{\circledR} 22 \mathrm{G}$ catheter is the most suitable for puncturing critical patients. Thus, the incorporation of new practices and technologies is necessary for success to occur in less time. Descriptors: Nursing; Pediatric Nursing; Nursing Care; Catheterization, Peripheral; Critical Care.

\section{RESUMO}

Objetivo: Verificar características relacionadas à criança crítica, ao cateter e ao profissional que influenciarão o tempo para o sucesso da punção. Método: Estudo descritivo, prospectivo e correlação, coletado com instrumento próprio, com amostra composta por 89 crianças atendidas na sala de emergência. Realizou-se análise estatística de associação entre o tempo e as variáveis explicativas considerando significância de $5 \%$. Resultado: 0 tempo médio para o sucesso foi 193,4 segundos. Análise multivariada mostrou que pacientes hipotérmicos $(p=0,009)$ apresentaram tempos prolongados para o sucesso e que a punção é realizada em menor tempo com cateter de Vialon ${ }^{\oplus} 22 \mathrm{G}(\mathrm{p}=0,045)$. Conclusão: $\mathrm{O}$ tempo médio para sucesso foi superior ao recomendado, sendo influenciado pela hipotermia e rede venosa comprometida das crianças. O cateter de Vialon ${ }^{\circledast} 22 \mathrm{G}$ é o mais indicado para puncionar pacientes críticos. Assim, a incorporação de novas práticas e tecnologias se faz necessário para que o sucesso ocorra em menor tempo.

Descritores: Enfermagem; Enfermagem Pediátrica; Cuidados de Enfermagem; Cateterismo Periférico; Cuidados Críticos.

\section{RESUMEN}

Objetivo: Comprobar las características relacionadas al niño en situación crítica, al catéter y al profesional que ejercerán influencia en el tiempo de punción. Método: Estudio descriptivo, prospectivo y correlacional, recolectado con instrumento propio, con muestra de 89 niños atendidos en la sala de urgencias. Se realizó el análisis estadístico para asociar el tiempo con las variables explicativas considerando nivel de significancia del 5\%. Resultado: El tiempo promedio fue de 193,4 segundos. El análisis multivariado demostró que los pacientes hipotérmicos $(p=0,009)$ presentaron tiempos prolongados para el éxito y que la punción se realiza en menor tiempo con el catéter de Vialon ${ }^{\oplus} 22 \mathrm{G}(\mathrm{p}=0,045)$. Conclusión: El tiempo promedio para el éxito fue superior a lo recomendado, siendo influenciado por la hipotermia y la red venosa comprometida. El catéter de Vialon ${ }^{\circledR} 22 \mathrm{G}$ es lo más indicado para puncionar pacientes en situación crítica. Hace necesario la incorporación de nuevas prácticas y tecnologías para que alcance el éxito en menor tiempo.

Descriptores: Enfermería; Enfermería Pediátrica; Atención de Enfermería; Cateterismo Periférico; Cuidados Críticos. 


\section{INTRODUCTION}

The practice of intravenous therapy in children in emergency situations is part of the care provided by the health team. The success in peripheral intravenous puncture in these patients may be difficult for the nursing team, since not all procedures are successful in the first attempt, resulting in an increase in the performance time, consequently interfering with the final care ${ }^{(1)}$. Thus, understanding the factors that involve the failure of puncture in critically ill children will provide evidence to improve this practice and favor its achievement in less time.

Although peripheral intravenous catheterization is part of the activities of nursing professionals, factors related to the physical and clinical characteristics of the child, in addition to the type and quality of the materials used, may hinder the puncture, and consequently increase the performance time of the procedure as well as interfere in the treatment ${ }^{(2-3)}$.

Studies conducted to verify the attendance of children to emergency rooms and the profile of the child population cared for reveal that from 0.3 to $3.3 \%$ of children need cardiopulmonary resuscitation and 57 to $60 \%$ of these patients undergo peripheral intravenous puncture ${ }^{(4-5)}$.

Risk factors related to the patient that lead to multiple procedures and longer puncture time, such as age below three years, present low weight or obesity, history of prematurity, skin color, psychomotor agitation, anxiety or fear, vascular diseases, or acute affections that interfere in blood circulation, e.g. dehydration or shock of varying etiology, determine greater vascular fragility, interference in visualization and palpation of the vessel, among other difficulties for the success of the procedure ${ }^{(3,6-7)}$.

The type and material of the catheter used influence the catheterization, since, depending on the flexibility, the device's handgrip to perform the puncture, and the device's caliber, the professionals may have difficulties or facilities to perform the procedure ${ }^{(8-9)}$.

The last European consensus for emergency care establishes the mark of 120 seconds for obtaining the puncture in critically ill children ${ }^{(10)}$. Research shows that the median time for the success of puncture in children may vary from 68 to 167 seconds ${ }^{(1,11)}$.

In view of the risk factors for the success of peripheral intravenous catheterization in children, this study verified which characteristics related to the patient, material used to perform the procedure, and professional team may interfere with the time for the success of the peripheral intravenous puncture.

\section{OBJECTIVE}

To verify the characteristics related to the child, catheter used, and the professional who performed the procedure that may influence the time for the success of punctures in an emergency situation.

Thus, we intended to institute an intravenous therapy plan for critical children punctured in an emergency situation, so that the procedure is performed with fewer attempts and less time for success.

\section{METHOD}

\section{Ethical aspects}

Data were collected after approval of the Research Ethics Committees of the Federal University of São Paulo (CEP 1869/08) and of the University Hospital of the University of São Paulo (CEP 839/08) in compliance with resolution 466 of December 12, 2012 of the National Health Council, Ministry of Health, which regulates research with human beings in the country.

The children selected for the study were included only after their parents or legal guardians signed the informed consent form. The professionals who punctioned the children also signed the informed consent form.

\section{Study design, location, and period}

This is a descriptive, prospective, and correlation study carried out in the pediatric Emergency Department of the University Hospital of the University of São Paulo. Data were collected in the period of one year, from March 2009 to March 2010.

\section{Population or sample; inclusion and exclusion criteria}

From a retrospective study carried out in the unit where the study was conducted, a consecutive convenience sample was determined limited for 100 children. However, after six months, we found that the sample did not reach the desired number of children and we extended it to one year, this being the time limit for the conclusion of the study. Thus, we determined the convenience sample limited to the time of data collection and development of the research, consisting of 89 children, aged between zero and 14 years, who were punctured during emergency care and were successful in the procedure.

The inclusion criterion of the children in the study was the successful accomplishment of the peripheral intravenous puncture during treatment in the pediatric emergency room. Children admitted to the emergency room and who already possessed an intravenous device were excluded from the study.

\section{Study protocol}

The data were collected in unique instrument developed by the researchers. Prior to data collection, the nurses of the institution were trained by the researcher to collect the information and procedures that involved it, following a manual elaborated for this purpose and that remained in the unit during the entire collection period. Prior to the beginning of the research, the instrument was pre-tested and the procedures employed for the research were observed to verify the adequacy of the training.

The data collection instrument was constructed following the sequence of care performed by the professionals of the unit during the children's assistance and peripheral intravenous puncture, with the objective of facilitating the filling and depict how the procedure was carried out by the team, being filled out by the responsible nurses who attended the emergency, immediately after stabilization of the patient, with the vital parameters evaluated during the realization of the peripheral intravenous puncture.

The variables related to the children, to the peripheral intravenous puncture, and to the professional who performed the procedure were studied.

Regarding the characteristics of the children, the age group was classified, as recommended by the Ministry of Health ${ }^{(12)}$, in infants ( 0 
to $<2$ years), preschool children ( 2 to $<7$ years), and school children ( $>7$ years). Sex was divided in male and female. For weight estimation, the Broselow ${ }^{\circledast}$ measuring tape was used, due to the impossibility of weighing the children during emergency care. The Broselow ${ }^{\oplus}$ tape helps to calculate the dose of drugs used during care, as well as to choose the devices to be used, such as intubation cannula and peripheral intravenous catheters ${ }^{(13)}$. To classify the weight of the patients, the weight estimation, sex, and age in months were used, following the recommendations of the growth curves of the World Health Organization $^{(14)}$. The weight was classified as adequate, high, low, and very low.

Skin pigmentation may interfere with visualization of the veins in people with brown and black skin color. Thus, the skin color variable was classified as white and nonwhite, the latter consisting of patients with brown and black skin color. The color of the skin was considered through the declaration of the legal guardian of the child when filling the institution's service sheet ${ }^{(15)}$.

The vital parameters were composed by blood pressure, oxygen saturation, axillary temperature, and peripheral capillary refill. Blood pressure was measured by electronic devices and cuffs suitable for each age. Classification followed the recommendations of the American Heart Association ${ }^{(8)}$. Oxygen saturation was measured using luminous sensors that measured the oxygenation of arterial hemoglobin, being classified as adequate (saturation $\geq 95 \%$ ) or inadequate (saturation $\leq 95 \%$ ). The axillary temperature was measured by a digital axillary thermometer, remaining in the region for one minute, at least, and was classified as hypothermia (temperature between $33^{\circ} \mathrm{C}$ and $35.9^{\circ} \mathrm{C}$ ), normothermia (temperature between $36^{\circ} \mathrm{C}$ and $37.7^{\circ} \mathrm{C}$ ), and hyperthermia or fever (temperature over $37.8^{\circ} \mathrm{C}$ ). The peripheral capillary refill was measured after elevation of the arm above the cardiac level and pressing the nail bed, then the filling time was verified, being classified in adequate (time $\leq 2$ seconds) or inadequate (time $\geq 3$ seconds) $)^{(8)}$.

The clinical conditions of the child at the time of admission to the emergency room were classified according to the main injuries mentioned by the American Heart Association ${ }^{(8)}$ and more frequent diseases present in the pediatric ED, such as trauma, cardiorespiratory arrest, shock, seizure, among others.

The predisposing conditions for unsuccessful venipuncture were determined from the evaluations of the nurses who performed the procedures and were identified as difficult-to-see veins, tortuous veins, small veins, agitation, fever, presence of hematomas by previous punctures, a lack of palpable veins, difficulty in stabilizing the veins and no difficulty.

The variables related to the peripheral intravenous puncture were: number of attempts; type and caliber of the peripheral intravenous catheter; time for the success of peripheral intravenous puncture; and vessel in which the device was inserted.

The peripheral intravenous puncture was considered successful when the procedure resulted in blood reflux and infusion of one milliliter of saline solution, the catheter was fixated, and there was no sign of complications concerning the intravenous therapy ${ }^{(6)}$.

The number of puncture attempts was defined by the number of times the professional attempted to puncture the child until the procedure was successful(6).

Three types of devices were used: one needled, named "A", of 25 gauge caliber; and two of the out of the needle type, one named " $B$ ", made of polyurethane and polytetrafluoroethylene that possessed the automatic needle recapping property, and another named " $\mathrm{C}$ ", in Vialon ${ }^{\circledast}$, with flexible, anti-skid wings, flexible transparent extender tube, and a device for needle recapping, both in 22 and 24 gauge caliber. The catheter was chosen by the professional who performed the procedure, after assessing the child's veins.

The time to perform the puncture was measured by the professional assigned to assist the peripheral intravenous catheterization, using a digital chronometer of the Stopwatch ${ }^{\circledast}$ brand. The equipment was triggered at the time of the garrotting of the child's limb and disconnected after fixation of the catheter ${ }^{(1)}$. The procedure was performed in the following sequence: member's garrotting; skin antisepsis; peripheral intravenous puncture; infusion of one milliliter of saline solution; and fixation of the device.

The insertion vessels of the device were marked in a figure that contained the peripheral veins and were classified into: dorsal venous arch of the hand; median cubital cephalic vein; cephalic vein; dorsal metacarpal vein of the hand; dorsal venous arch of the foot; antebrachial vein; and basilic vein. The choice of the vessel to be punctured occurred after evaluation by the professional, determining the site, which should not interfere in the emergency care, and the caliber, which should be the most calibrated for rapid infusion of drugs and solutions.

The variables referring to the professionals who performed the procedure were: professional category (nurse, nursing technician and nursing assistant); workload; activities developed before the puncture; and work shift.

The work activity developed before the puncture was considered, in this study, as the actual work effectively performed by the professional until the execution of the procedure, being analyzed to verify whether the physical and mental exhaustion resulting of its implementation might interfere with the time of the procedure ${ }^{(16)}$. The two work activities performed by the professionals were to provide integral care to the child and to prepare and administer medications to the patient.

The work shifts in the institution are divided in morning, afternoon, and night, the first two having a duration of 6 hours and the third of 12 hours. Thus, the morning and afternoon shifts were divided into two periods of 3 hours each $\left(1^{\text {st }}\right.$ morning, $2^{\text {nd }}$ morning; $1^{\text {st }}$ afternoon, $2^{\text {nd }}$ afternoon) and the night shift in four periods of 3 hours ( $1^{\text {st }}$ night, $2^{\text {nd }}$ night, $3^{\text {rd }}$ night, $4^{\text {th }}$ night $)$, so that the analysis was similar among them, as well as to verify if the execution time of the procedure would differ between the periods.

\section{Analysis of the results and statistics}

The associations were made between the variable puncture time, which was described by measurement of position (mean, median, minimum, and maximum) and scale (standard deviation and interquartile interval), and the explanatory variables related to the child, to the device used and the professional who performed the puncture. The Mann-Whitney or Kruskal-Wallis statistical testes were used for this analysis. Based on the results of the associations, generalized linear models with inverse normal distribution and binding function $\mu^{2}$ were adjusted, considering only the explanatory variables referring to the characteristics of the children and of the intravenous therapy that had a $p$-value of less than 0.2. A model with the variables referring to the professional was not proposed, since none of them presented 
association in the initial tests. The analyses considered a significance level of $5 \%$ and were performed with the aid of the software R 3.2.2.

\section{RESULTS}

Data from 89 children were analyzed, as shown in Figure 1.

The characteristics of the children are indicated in Table 1. The mean time was higher in infants, male, hypertensive, hypothermic, with adequate oxygenation, and inadequate peripheral capillary refill. The statistically significant results were found regarding patients with low weight and white skin color, who presented longer time to obtain the success of peripheral intravenous puncture.

Regarding the predisposing conditions for the failure of peripheral intravenous puncture evaluated by the professionals, it is possible to verify in Table 2 that the mean time to install the catheter was higher among children who had difficult-to-see veins, small veins, a lack of palpable veins, and who had a fever, with a statistically significant difference being identified.

The mean time for the success of the peripheral intravenous puncture was $193.4( \pm 180.9)$ seconds, and its distribution was asymmetric. One hundred and fifty-one punctures were performed in the 89 patients submitted to the procedure, with success being obtained for $53.9 \%$ in the first attempt, $29.2 \%$ in the second attempt, and $13.5 \%$ until the third attempt. The number of attempts ranged from 1 to 7 punctures. Regarding the mean time for the success of the peripheral intravenous puncture and the number of attempts, we observed that the greater the number of attempts generated, the greater the time for success of the procedure.

Regarding the variables related to the peripheral intravenous catheterization, Table 3 shows that the time of puncture success was lower when the type C, $22 \mathrm{G}$ caliber catheter was used. The vessels punctured with shorter time were the dorsal venous arch of the hand and the median cubital cephalic vein.

Table 4 shows, concerning the characteristics of the professionals who performed the peripheral intravenous puncture, that the success in the procedure was obtained in less time by nursing technicians who had a weekly workload of 36 hours, activity developed before puncture was integral care, and who worked in the first morning period.

For the multivariate analysis and adjustment of the final model, the nonnormal distribution for the time of success of the puncture was considered. The first analysis for the construction of the multivariate model related to the characteristics of the child considered the variables that had a $p$-value lower than 0.2. After the first analysis, we found that some variables did not interfere in the time for the success of

Note:'Kruskal-Wallis test: ${ }^{2}$ Mann-Whitney test. the puncture. Thus, the final model, adjusted after exclusion of the variables that interfered in the puncture time, showed that the mean time reduced significantly in children with high weight (estimate 0.000343 and $p=0.017$ ) and that hypothermic patients presented longer time for the success of the puncture (estimate -0.000030 and $p=0.009$ ).

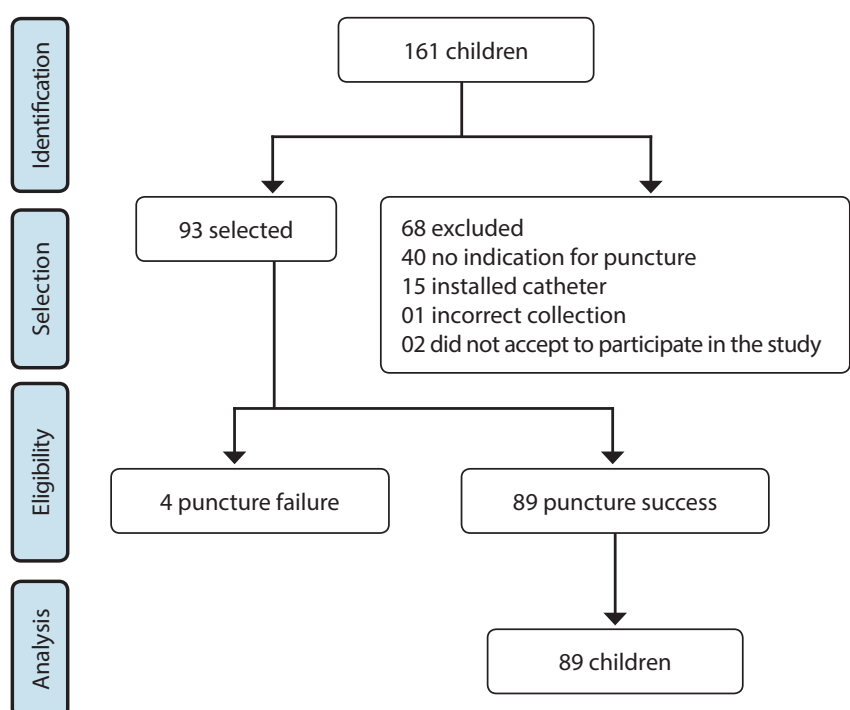

Figure 1 - Flowchart of the study participants, São Paulo, São Paulo, Brazil, 2010

Table 1 - Median and interquartile interval of the characteristics of the child, according to time for the success of the peripheral intravenous puncture, São Paulo, São Paulo, Brazil, 2010

\begin{tabular}{|c|c|c|c|}
\hline Variable & & $\begin{array}{l}\text { Puncture time (seconds) } \\
\text { Median [Interquartile } \\
\text { range] }\end{array}$ & $\begin{array}{c}p \\
\text { value }\end{array}$ \\
\hline Age group & $\begin{array}{l}\text { Infant }(n=27) \\
\text { Preschool children }(n=50) \\
\text { School children }(n=12)\end{array}$ & $\begin{array}{c}162.0[94.5-256.0] \\
149.0[80.0-238.0] \\
87.0[65.2-155.5]\end{array}$ & $0.184^{1}$ \\
\hline Sex & $\begin{array}{l}\text { Male }(n=51) \\
\text { Female }(n=38)\end{array}$ & $\begin{array}{l}124.0[78.0-235.0] \\
163.0[92.0-238.8]\end{array}$ & $0.667^{2}$ \\
\hline Estimation of the nutrition degree & $\begin{array}{l}\text { Adequate weight }(n=74) \\
\text { High weight }(n=5) \\
\text { Low weight }(n=7) \\
\text { Very low weight }(n=3)\end{array}$ & $\begin{array}{c}139.0[83.0-237.0] \\
52.0[47.0-55.0] \\
235.5[162.5-324.0] \\
178.0[126.0-199.0]\end{array}$ & $0.004^{1}$ \\
\hline Skin color & $\begin{array}{l}\text { Nonwhite }(n=36) \\
\text { White }(n=53)\end{array}$ & $\begin{array}{l}116.0[69.8-189.8] \\
169.0[94.5-247.0]\end{array}$ & $0.038^{2}$ \\
\hline Clinical conditions & $\begin{array}{l}\text { Shocks }(n=9) \\
\text { Seizure }(n=53) \\
\text { Respiratory affections }(n=16) \\
\text { Others }(n=11)\end{array}$ & $\begin{array}{c}176.0[139.0-336.5] \\
120.0[74.0-220.0] \\
130.5[77.0-211.0] \\
134.0[106.0-391.5]\end{array}$ & $0.292^{1}$ \\
\hline Systolic blood pressure & $\begin{array}{l}\text { Hypertensive }(n=30) \\
\text { Normotensive }(n=29) \\
\text { Hypotensive }(n=15)\end{array}$ & $\begin{array}{l}176.5[91.8-251.5] \\
116.0[73.0-194.0] \\
163.0[95.0-309.0]\end{array}$ & $0.255^{1}$ \\
\hline Oxygen saturation & $\begin{array}{l}\text { Adequate oxygenation }(n=71) \\
\text { Inadequate oxygenation }(n=18)\end{array}$ & $\begin{array}{l}140.0[83.0-237.0] \\
118.5[77.0-235.8]\end{array}$ & $0.597^{2}$ \\
\hline Peripheral capillary refill & $\begin{array}{l}\text { Inadequate }(n=52) \\
\text { Adequate }(n=35)\end{array}$ & $\begin{array}{l}149.5[74.8-237.8] \\
126.0[91.5-225.0]\end{array}$ & $0.848^{2}$ \\
\hline Temperature & $\begin{array}{l}\text { Fever }(n=35) \\
\text { Normothermia }(n=31) \\
\text { Hypothermia }(n=21)\end{array}$ & $\begin{array}{c}120.0[68.0-193.0] \\
124.0[83.0-245.0] \\
198.0[114.0-396.0]\end{array}$ & $0.146^{2}$ \\
\hline
\end{tabular}


Table 2 - Median and interquartile range of the predisposing conditions for failure of the peripheral intravenous puncture, according to time for the success of the procedure, São Paulo, São Paulo, Brazil, 2010

\begin{tabular}{|c|c|c|c|}
\hline Variable & & $\begin{array}{c}\text { Puncture time } \\
\text { (seconds) } \\
\text { Median [Interquartile } \\
\text { range] }\end{array}$ & $\begin{array}{c}p \\
\text { value }\end{array}$ \\
\hline Difficult-to-see veins & $\begin{array}{l}\text { No }(n=64) \\
\text { Yes }(n=25)\end{array}$ & $\begin{array}{l}120.0[78.0-225.0] \\
180.0[132.5-416.0]\end{array}$ & $0.022^{1}$ \\
\hline Tortuous veins & $\begin{array}{l}\text { No }(n=79) \\
\text { Yes }(n=10)\end{array}$ & $\begin{array}{l}136.0[79.2-233.8] \\
194.0[131.5-443.5]\end{array}$ & $0.291^{1}$ \\
\hline Small veins & $\begin{array}{l}\text { No }(n=81) \\
\text { Yes }(n=8)\end{array}$ & $\begin{array}{l}125.0[78.0-217.5] \\
401.0[149.0-520.0]\end{array}$ & $0.008^{1}$ \\
\hline Agitation & $\begin{array}{l}\text { No }(n=37) \\
\text { Yes }(n=52)\end{array}$ & $\begin{array}{l}140.0[86.0-398.5] \\
136.0[78.2-233.8]\end{array}$ & $0.511^{1}$ \\
\hline Fever & $\begin{array}{l}\text { No }(n=72) \\
\text { Yes }(n=17)\end{array}$ & $\begin{array}{l}124.0[74.5-232.5] \\
178.5[127.2-249]\end{array}$ & $0.052^{1}$ \\
\hline Presence of hematomas by previous punctures & $\begin{array}{l}\text { No }(n=85) \\
\text { Yes }(n=4)\end{array}$ & $\begin{array}{l}138.0[80.0-235.0] \\
325.5[183.2-461.5]\end{array}$ & $0.208^{1}$ \\
\hline A lack of palpable veins & $\begin{array}{l}\text { Absent }(n=74) \\
\text { Present }(n=15)\end{array}$ & $\begin{array}{l}125.0[74.8-231.2] \\
194.0[116.0-431.0]\end{array}$ & $0.024^{1}$ \\
\hline Difficulty in stabilizing the vessel & $\begin{array}{l}\text { No }(n=86) \\
\text { Yes }(n=3)\end{array}$ & $\begin{array}{l}136.0[79.2-233.8] \\
396.0[295-413.5]\end{array}$ & $0.076^{1}$ \\
\hline No difficulty & $\begin{array}{l}\text { No }(n=66) \\
\text { Yes }(n=23)\end{array}$ & $\begin{array}{l}167.5[93.0-243.0] \\
93.0[67.0-139.5]\end{array}$ & $0.028^{1}$ \\
\hline
\end{tabular}

Note: ${ }^{1}$ Mann-Whitney test.

Table 3 - Median and interquartile interval of the characteristics of the peripheral intravenous catheterization, according to time for the success of the peripheral intravenous puncture, São Paulo, São Paulo, Brazil, 2010

\begin{tabular}{|c|c|c|c|}
\hline Variable & & $\begin{array}{c}\text { Puncture time } \\
\text { (seconds) } \\
\text { Median [Interquartile } \\
\text { range] }\end{array}$ & $\underset{\text { value }}{p}$ \\
\hline Device caliber & $\begin{array}{l}22(n=12) \\
24(n=76) \\
25(n=01)\end{array}$ & $\begin{array}{c}101.5[66.8-150.0] \\
144.0[80.8-237.8] \\
238.0[238.0-238.0]\end{array}$ & $0.195^{1}$ \\
\hline Catheter type & $\begin{array}{l}C(n=42) \\
B(n=46) \\
A(n=01)\end{array}$ & $\begin{array}{c}115.0[67.5-188.2] \\
166.5[91.5-247.5] \\
238.0[238.0-238.0]\end{array}$ & $0.149^{1}$ \\
\hline Catheter insertion vessel & $\begin{array}{l}\text { Dorsal venous arch of the hand }(n=42) \\
\text { Median cubital cephalic vein }(n=31) \\
\text { Cephalic vein }(n=4) \\
\text { Dorsal metacarpal vein of the hand }(n=2) \\
\text { Dorsal venous arch of the foot }(n=6) \\
\text { Antebrachial vein }(n=2) \\
\text { Basilic vein }(n=2)\end{array}$ & $\begin{array}{c}122.0[78.2-231.2] \\
122.0[76.5-201.0] \\
124.5[74.5-164.5] \\
125.0[88.5-161.5] \\
187.0[124.5-231.5] \\
351.0[294.0-408.0] \\
265.0[257.5-272.5]\end{array}$ & $0.260^{1}$ \\
\hline
\end{tabular}

Note: ${ }^{1}$ Kruskal-Wallis test.

Table 4 - Median and interquartile interval of the characteristics of the professionals who performed the procedure, according to time for the success of the peripheral intravenous puncture, São Paulo, São Paulo, Brazil, 2010

\begin{tabular}{llcc}
\hline Variable & & $\begin{array}{c}\text { Puncture time (seconds) } \\
\text { Median [Interquartile range] }\end{array}$ & $\begin{array}{c}\boldsymbol{p} \\
\text { value }\end{array}$ \\
\hline Professional category & Nurse $(\mathrm{n}=51)$ & $126.0[86.0-220.0]$ & $0.404^{1}$ \\
& Nursing technician $(\mathrm{n}=14)$ & $95.5[68.2-200.0]$ & $174.0[70.2-258.2]$ \\
& Nursing assistant $(\mathrm{n}=24)$ & $126.0[78.0-237.0]$ & $0.906^{1}$ \\
Weekly workload & $36 \mathrm{~h}(\mathrm{n}=69)$ & $160.0[116.5-163.0]$ & $149.0[95.0-210.0]$ \\
\hline
\end{tabular}

Regarding the characteristics of the peripheral intravenous catheterization, one child punctured with the device A with a $25 \mathrm{G}$ caliber was excluded. The initial analysis of the interaction between the variables "caliber" and "type" of the device with the mean time of success showed that it varies between the calibers differently for each device and that the interaction effect was significant. The final model showed that the mean puncture time performed by the type C, $22 \mathrm{G}$ caliber device is lower compared to the $24 \mathrm{G}$ caliber device of the same type, and the result was statistically significant (estimate 0.000102 and $p=0.045$ ). There was a difference of 110 seconds with a confidence interval of $95 \%$ from 35.4 to 186.4 seconds favoring the $22 \mathrm{G}$ caliber compared to the $24 \mathrm{G}$ caliber for device $C$.

\section{DISCUSSION}

The mean time for the success of the peripheral intravenous puncture was higher than the 120 seconds recommended to perform the procedure in critically ill patient ${ }^{(10)}$, because in this study $46.1 \%$ of the children required two or more punctures for the catheter to be installed. Patients who underwent only one peripheral intravenous catheterization presented a mean time of 90 seconds.

The clinical conditions of the child at the time of admission to the emergency unit may interfere, facilitating or hindering, the beginning of the administration of the solutions and drugs necessary for the care of critically ill patients ${ }^{(1)}$.

In this investigation, we observed in the univariate analysis that the mean time for the success of the puncture was higher among infants, confirming data from the literature that demonstrated that in children aged under two years it is more difficult to succeed in the first attempt, since their peripheral veins are adhered to the connective tissue, making them more fragile ${ }^{(3,6-7)}$.

Children with high weight had significant reduction in the time for puncture success. A study carried out with the aim of verifying factors that could influence the success of 
Table 4 (concluded)

\begin{tabular}{llcc}
\hline Variable & & $\begin{array}{c}\text { Puncture time (seconds) } \\
\text { Median [Interquartile range] }\end{array}$ & $\begin{array}{c}\boldsymbol{p} \\
\text { value }\end{array}$ \\
\hline $\begin{array}{l}\text { Activity developed } \\
\text { before the puncture }\end{array}$ & Providing integral care $(\mathrm{n}=72)$ & $123.0[79.8-210.0]$ & $0.327^{1}$ \\
Work shift time & $1^{\text {st }}$ morning $(\mathrm{n}=6)$ & $180.0[75.0-274.0]$ & $98.5[75.0-133.2]$ \\
& $2^{\text {nd }}$ morning $(\mathrm{n}=12)$ & $167.5[102.8-265.2]$ \\
& $1^{\text {st }}$ afternoon $(\mathrm{n}=8)$ & $171.0[106.8-538.0]$ \\
& $2^{\text {nd }}$ afternoon $(\mathrm{n}=17)$ & $126.0[92.0-198.0]$ \\
& $1^{\text {st }}$ night $(\mathrm{n}=17)$ & $134.0[79.0-240.0]$ \\
& $2^{\text {nd }}$ night $(\mathrm{n}=13)$ & $112.5[75.0-226.8]$ & $0.751^{1}$ \\
& $3^{\text {rd }}$ night $(\mathrm{n}=7)$ & $180.0[141.0-223.5]$ \\
& $4^{\text {th }}$ night $(\mathrm{n}=9)$ & $150.0[98.5-237.8]$
\end{tabular}

Note: ${ }^{1}$ Kruskal-Wallis test.

peripheral intravenous catheterization of children found that there is an inverse relationship between mean time for success of the puncture and weight ${ }^{(6)}$. Children classified as obese have difficultto-see veins and palpation, because they have a larger layer of adipose tissue, while children with low weight have small veins ${ }^{(15)}$.

The hemodynamic instability of critically ill patients results in peripheral vasoconstriction, affecting the peripheral evaluation of the veins, making the vessels difficult to palpate and visualize and also fragile ${ }^{(3,6,15-17)}$. Also, hypothermia is associated with peripheral vasoconstriction and impairment of visualization and palpation of peripheral veins, hindering the success of the procedure ${ }^{(10)}$. This research confirmed in the multivariate analysis that hypothermia interfered in the time for success of the puncture.

Concerning the predisposing conditions for the failure of the peripheral intravenous puncture, we verified that the mean time to perform the procedure were higher in children who had difficult-to-see veins and palpation, and small veins, the latter being a predictive factor for the increase in the mean time of the procedure. Research conducted to identify the factors influencing the success of peripheral intravenous catheter insertion found that the main problems reported by the professionals were: difficulty to stabilize the vase; non-visible and non-palpable veins; small veins; and location of the vessels ${ }^{(15,18)}$.

Studies that used technologies, such as the use of transillumination equipment with diodes or infrared emitting lights and ultrasonography, to increase the visualization of the peripheral veins verified a higher success rate of the catheterization and significant reduction in procedure time in children with difficult venous access ${ }^{(15,18-21)}$. Thus, the use of these technologies to visualize the veins in an emergency situation, associated with the rapid evaluation of the child to be punctured, is an alternative to increase the success of the procedure and reduce the time of puncture.

The shortest time of success in the puncture was obtained with a type $\mathrm{C}$ device, and this fact can be explained by the provision of a better handgrip to the professional. The recommendation of the use of larger calibers when puncturing children in emergency situations is valid in this study, as we showed by multiple comparison a better time for the success of the puncture with $22 \mathrm{G}$ caliber devices compared to those of $24 \mathrm{G}$ caliber $^{(8)}$.

The insertion of the peripheral intravenous catheter should occur in a place that does not interfere with emergency care ${ }^{(8)}$. In this study, the shorter times of success of the procedure occurred in the veins of the upper limbs, such as the dorsal venous arch of the hand, followed by the median cubital cephalic vein, thus showing that the upper limbs are places of better access and easy visualization to perform the peripheral intravenous puncture of children in emergency situations $s^{(3,18)}$.

Regarding the professionals who performed the peripheral intravenous puncture, although they were not considered in the model for multivariate analysis, we found that the longest time for success occurred with nursing assistants. This confirms the need for a qualified professional approach due to the complexity of this care, and that the professional who performs the procedure needs to have scientific knowledge and technical ability regarding intravenous therapy ${ }^{(9)}$.

The working conditions of nursing professionals can also disfavor safe practice. In this investigation, we verified that the longest time for the success of the puncture occurred among professionals who worked 60 hours a week, who had as activity preceding the procedure the preparation and administration of medications and who were in third period of the night shift. Such factors could increase the physical and mental exhaustion of the professional who performed the puncture, thus interfering in the care provided ${ }^{(22)}$.

In the face of these results, we suggest that resources to facilitate peripheral intravenous catheterization are used. Transilluminator, ultrasonography, and fluoroscopy are alternatives that can facilitate the procedure in children in emergency situations and have been shown to be viable alternatives, as they promote better visualization of the veins ${ }^{(2,15-21)}$.

\section{Study limitation}

We analyzed 89 children who were successful in peripheral intravenous puncture, assisted in an emergency situation, in the period of one year. More scientific evidence would be identified if the sample was larger.

\section{Contributions to the field of nursing}

Knowing the characteristics of the children undergoing intravenous therapy and factors influencing the time for the success of the intravenous puncture contributes to nurses' planning regarding this practice. The study contributes in this sense, as it confirms characteristics related to the patient that interfere in the time of the success of the procedure, as well as identifying a puncture device that can reduce the time and increase the success of the procedure in children in an emergency situation.

\section{CONCLUSION}

The mean time for success was 193 seconds, higher than recommended by the literature. In the multivariate analysis, the variable that interfered with the highest average time for the success of the puncture was hypothermia. High weight was a reduction factor concerning the time of peripheral intravenous catheterization. 
The type C, 22G caliber out of the needle catheter proved to be the most suitable device for puncturing children in emergency situations. At the end of this investigation, we found that there is a need to incorporate new practices and technologies so that the time of success of peripheral intravenous puncture is lower and closer to the recommended by the literature.

\section{REFERENCES}

1. Parker SIA, Benzies KM, Hayden KA. A systematic review: effectiveness of pediatric peripheral intravenous catheterization strategies. J Adv Nurs. 2016;73(3):1570-82. doi: 10.1111/jan.13211

2. Kuensting LL, DeBoer S, Holleran R, Shultz BL, Steinmann RA, Venella J. Difficult venous access in children: taking control. J Emerg Nurs. 2009;35(5):419-24. doi: 10.1016/j.jen.2009.01.014

3. Cuper NJ, De Graaff JC, van Dijk ATH, Verdaasdonk RM, van der Werff DBM, Kalkman CJ. Predictive factors for difficult intravenous cannulation in pediatric patients at a tertiary pediatric hospital. Paediatr Anaesth. 2012;22(3):223-9. doi: 10.1111/j.1460-9592.2011.03685.x

4. Salgado RMP, Aguero FCM. Profile of pediatric patients treated at emergency room of a university hospital. Pediatria (São Paulo). 2010 ;32(2):90-7.

5. Guilfoyle FJ, Milner R, Kisson N. Resuscitation interventions in a tertiary level pediatric emergency department: implications for maintenance of skills. CJEM. 2011;13(2):90-5. doi: 10.2310/8000.2011.110230

6. Larsen P, Eldridge D, Brinkley J, Newton D, Goff D, Hartzog T, et al. Pediatric peripheral intravenous access: does nursing experience and competence really make a difference? J Infus Nurs. 2010;33(4):226-35. doi: 10.1097/NAN.0b013e3181e3a0a8

7. Reigart JR, Chamberlain KH, Eldridge D, O'Brien ES, Freeland KD, Larsen $P$, et al. Peripheral Intravenous Access in pediatric inpatients. Clin Pediatr. 2012;51(5):468-72. doi: 10.1177\%2F0009922811435164

8. Caen AR, Berg MD, Chameides L, Gooden CK, Hickey RWH, Scott HF, et al. Part 12: pediatric advanced life support: 2015 American Heart Association guidelines update for cardiopulmonary resuscitation and emergency cardiovascular care. Circulation. 2015;132(18 Suppl 2):S526-42. doi: $10.1161 / C I R .0000000000000266$

9. Gorski L, Hadaway L, Hagle ME, McGoldrick M, Orr M, Doellman D. Infusion therapy standards of practice. J Infus Nurs [Internet]. 2016 [cited 2017 Nov 5];39(1S):S44-5. Available from: http://www.incativ.es/documentos/guias/INS\%20Standards\%20of\%20Practice\%202016_0.pdf

10. Prottengeier J, Albermann M, Heinrich S, Birkholz T, Gall C, Schmidt J. The prehospital intravenous access assessment: a prospective study on intravenous access failure and access delay in prehospital emergency medicine. Eur J Emerg Med. 2016;23(6):442-7. doi: 10.1097/ MEJ.0000000000000291

11. Chapman LL, Sullivan BS, Pacheco AL, Draleau CP, Becker BM. VeinViewer-assisted intravenous catheter placement in a pediatric emergency department. Acad Emerg Med. 2011;18(9):966-71. doi: 10.1111/j.1553-2712.2011.01155.x

12. Ministério da Saúde (BR). Secretaria de Atenção à Saúde. Departamento de Atenção Básica. Saúde da criança: crescimento e desenvolvimento. [Internet]. Brasília: Ministério da Saúde; 2012 [cited 2018 Mar 17]. (Cadernos de Atenção Básica, no 33). Available from: http://bvsms.saude.gov. br/bvs/publicacoes/saude_crianca_crescimento_desenvolvimento.pdf

13. Varghese A, Vasudevan VK, Lewin S, Indumathi CK, Dinakar C, Rao SDS. Do the length-based (Broselow ${ }^{\circledast}$ ) tape, APLS, Argall and Nelson's formulae accurately estimate weight of Indian children? Indian Pediatr [Internet]. 2006 [cited 2017 Nov 5];43(17):889-94. Available from: http://www.indianpediatrics.net/oct2006/889.pdf

14. World Health Organization (WHO). Growth curves. Geneva: WHO; 2007.

15. van der Woude OCP, Cuper NJ, Getrouw C, Kalkman CJ, de Graaff JC. The effectiveness of a near-infrared vascular imaging device to support intravenous cannulation in children with dark skin color: a cluster randomized clinical trial. Anesth Analg. 2013;116(6):1266-71. doi: 10.1213/ ANE.0b013e31828e5bde

16. Marziale MHP, Carvalho EC. Condições ergonômicas do trabalho da equipe de enfermagem em unidade de internação de cardiologia. Rev Latino-Am Enfermagem. 1998;6(1):99-117. doi: 10.1590/S0104-11691998000100013

17. Sabri A, Szalas J, Holmes KS, Labib L, Mussivand T. Failed attempts and improvement strategies in peripheral intravenous catheterization. Biomed Mater Eng. 2013;23(1-2):93-108. doi: 10.3233/BME-120735

18. Demir $D$, Inal $S$. Does the use of a vein visualization device for peripheral venous catheter placement increase success rate in pediatric patients? Pediatr Emerg Care. 2019;35(7):474-9. doi: 10.1097/PEC.0000000000001007

19. Graaff JC, Cuper NJ, van Dijk ATH, Timmers-Raijmakers BC, van der Werff DB, Kalkman CJ. Evaluating NIR vascular imaging to support intravenous cannulation in awake children difficult to cannulate; a randomized clinical trial. Paediatr Anaesth. 2014;24(11):1174-9. doi: 10.1111/pan.12501

20. Benkhadra M, Collignon M, Fournel I, Oeuvrard C, Rollin P, Perrin M, et al. Ultrasound guidance allows faster peripheral IV cannulation in children under 3 years of age with difficult venous access: a prospective randomized study. Paediatr Anaesth. 2012;22(5):449-54. doi: 10.1111/j.1460-9592.2012.03830.x

21. Cuper NJ, de Graaff JC, Verdaasdonk RM, Kalkman CJ. Near-infrared imaging in intravenous cannulation in children: a cluster randomized clinical trial. Pediatrics. 2013;131(1):e191-7. doi: 10.1542/peds.2012-0968

22. Silva BM, Lima FRF, Farias FSAB, Campos ACS. Working time: factors that interfere in the quality of nursing assistance. Texto Contexto Enferm. 2006;15(3):442-8. doi: 10.1590/S0104-07072006000300008 